OPEN ACCESS

Vol. 8, No. 2, Oktober, 2020

Page. 67-75

DOI: https://doi.org/10.21107/jaffa.v8i2.8349
JOURNAL OF AUDITING, FINANCE, AND FORENSIC ACCOUNTING

E-ISSN: 2461-0607 ISSN: 2339-2886

https://journal.trunojoyo.ac.id/jaffa

\title{
Client Pressures, Audit Tenure to Audit Quality: Moderation of Auditor Independence
}

\author{
1Muslim*; ${ }^{2}$ Hamzah Ahmad, 3Syamsuri Rahim, ${ }^{4}$ Muhammad Faisal AR Pelu \\ ${ }^{1234}$ Accounting Department, University of Muslim, Indonesia
}

\section{Article Info:}

Received: 21 August 2020

in revised form: 31 August 2020

Accepted: 1 October 2020

Available Online: 28 October 2020

\section{Keywords:}

Client Pressure, Audit Period, Audit Quality, Auditor Independence.

Corresponding Author*:

*Email: muslim.ak@umi.ac.id

\begin{abstract}
This study aims to examine the effect of client pressure and audit tenure on audit quality with auditor independence as a moderating variable in the Public Accounting Firm (KAP) in Makassar. The data in this study were obtained from each KAP in Makassar City who were willing to become respondents. This study uses primary data by conducting direct research in the field by providing questionnaires/question sheets to 45 respondents. The data analysis method used is moderated regression analysis (MRA). The results showed that client pressure had a positive and significant effect on audit quality. While the audit tenure variable has a negative and significant effect on audit quality. Auditor independence variable is a moderating variable that affects client pressure and audit quality.
\end{abstract}

Abstrak; Penelitian ini bertujuan untuk menguji pengaruh tekanan klien dan masa kerja audit terhadap kualitas audit dengan independensi auditor sebagai variabel moderasi pada Kantor Akuntan Publik (KAP) di Makassar. Data dalam penelitian ini diperoleh dari masing-masing KAP di Kota Makassar yang bersedia menjadi responden. Penelitian ini menggunakan data primer dengan memberikan kuesioner kepada 45 responden. Metode analisis data yang digunakan adalah analisis regresi moderasi (MRA). Hasil penelitian menunjukkan tekanan klien berpengaruh positif dan signifikan terhadap kualitas audit. Sedangkan variabel audit tenure berpengaruh negatif dan signifikan terhadap kualitas audit. Variabel Independensi Auditor merupakan variabel moderasi yang berpengaruh terhadap hubungan tekanan klien dan kualitas audit. 


\section{INTRODUCTION}

Financial statements presented by the company's management are a reflection of the company's financial condition as well as a form of accountability report on the performance of the company's management work as a manager to the owner of the company (Muslim et al., 2018). The interest between the owner and the management of the company to maximize his/her personal interests has the potential to trigger information contained in the financial statements incompatible with the company's actual condition. Stakeholders as decision makers certainly expect quality information without the influence of the personal interests of the company owner and the management of the company as the manager. Therefore, the role of public accountants to mediate such different interests as an independent party is heavily important (Lee, 1993; Abdillah \& Sabeni, 2013) which is to give an assessment and statement of opinion on the fairness of the financial statements presented. Panjaitan (2014) explained that more information quality can be improved by the presence of auditors as an independent party.

An independent auditor is one of the deciding factors to produce a fair assessment of financial statements good quality. Independence requires auditors to form public opinion as a professional profession, interest free and able to provide justice for all stakeholders. Ironically, for Public Accounting Firm (PAF) the existence of the company (client) is very important because the company is a source of income as well as a career benchmark of the Public Accounting Firm. Different conditions are felt by public accounting firms that have few clients because they are very vulnerable to pressure from clients.

The dilemma will continue to be given by the company's management to influence the vetting process in order to be able to fulfill its interests. Auditors who meet the client's personal interests may potentially violate professional ethical standards, but by not meeting the interests of the client then it is likely that the auditor could lose his client or his source of revenue (Triana, 2010). In this case the professional consideration of an auditor based on values and beliefs and moral awareness has an important role in audit decision making. The influence of superior pressure and the influence of client pressure tends to make auditors deviations and do not meet professional standards. This can affect the quality of audits while on the other hand auditors are also required to remain independent and maintain their objectivity, reporting findings that match those found in the field (Saputra et al., 2015).

Tenure by experts is described as the time in an audit engagement between KAP and the client about the audit process to be carried out. This period of engagement between KAP and the management of the company (auditee) will create an emotional connection and over a long period of time this relationship has the potential to cause closeness so as to hinder the independence of the auditor, lowering objectivity thus reducing the quality of the audit due to different interest factors (Beneish et al., 2004; Nazatul et al., 2006; Abedalqader Al-Thuneibat, Tawfiq Ibrahim Al Issa, \& Ata Baker, 2011; Dao \& Pham, 2014). Decreased objectivity will result in the possibility of increasing failures in detecting errors in financial statements. Results of the study (Sulfati, 2014; Kurniasih \& Rohman, 2014; Sari, 2012; Panjaitan, 2014) found that tenure was able to lower the quality of audits. These results contradict Gosh \& Moon's (2003) with the findings of the quality of the audit increased with the longer the audit tenure.

Until now, the measurement of audit quality is still unclear, therefore ordinary financial report users tend to see the auditor's reputation as a barometer for assessing audit quality because the public accounting firm that has a good reputation tends to maintain the quality of its audits (Rahim, 2016; Hajering et al., 2019; Syamsuriana et al., 2019; Pratiwi et al., 2020). The quality of the audit relates to the auditor's assurance that the financial statements do not present material errors or contain fraud. The quality of audits can be seen from the level of auditor compliance in carrying out various stages that should be carried out in an auditing activity (DeAngelo, 1981; Coram, Glavovic, Ng, \& Woodliff, 2004). It can be concluded that the quality of audits concerns the compliance of auditors in fulfilling procedural matters to ensure confidence in the reliableness of financial statements. This research relates to the attitude of auditor independence, client pressure and audit tenure and its impact on 
audit quality. The failure of auditors to maintain good audit quality will certainly have an impact on the decline of public trust and credibility towards the audit profession as an independent party (Wahyuni, 2019). This study uses auditor independence as variable moderating to see if independence owned by auditors is able to improve the quality of audits generated by public accountants.

This research topic is interesting because it turns out that the assignment of audits that take too long is likely to drive public accountants to lose their independence. However, other disi, the client will be satisfied because the public accountant is less strict in carrying out the audit procedure and his design can be fulfilled. On the other hand, the assignment of old audits may also increase independence because public accountants are familiar, the work can be carried out efficiently and more resistant to client pressure but make the client dissatisfied with the auditor's work because of his unfulfilled interests.

\section{LITERATURE REVIEW AND HYPOTHESES DEVELOPMENT}

\section{Agency Theory}

Agency theory is a theory describing the relationship between two individuals of different interests namely principals and agents. Hendriksen and Breda (1992) stated that the agency relationship is a contractual relationship between the principal and the agent, the principal delegating responsibility for a particular task in accordance with the agreed contract or decision-making to the agent. The agent will take the best course of action in the principal's interest. The principal will reward the agent's work. The authority and responsibility of the agent and principal are governed by the contract of employment upon mutual consent (Ujiyhanto, 2010). Agency matters will arise in the event of a conflict of interest between the principal and the agent in order to maximize their respective personal interests (Rahim et al., 2019). The principal assesses the agent's achievements based on his ability to increase profits. The higher the amount of profit generated by the agent (management), the higher the dividend, then the agent is considered successful or performing well so that it deserves a high incentive (Elqorni, 2009). Auditors as third parties are required to supervise the performance of management whether it has acted in accordance with the principal's interests through financial statements (Rudyawan \& Badera, 2008). Auditors must be independent parties that are not easily affected by tenure (long-standing client audit alliances with auditors), so that the results of the supervision carried out are objective evidence.

\section{Client Presure and Audit Quality}

Pressure from the client may arise when between the auditor and the management or the client disagrees with some aspects of the results of the financial report testing. The Client seeks to influence the function of testing financial statements by auditors to perform actions that violate auditing standards, including in providing opinions that do not suit the client's circumstances. The company's management wants to show that the company's performance is good, which is usually seen from high profits. To achieve these goals, companies often put pressure on auditors. This situation makes the auditor run into an ethical dilemma, on the one hand if the auditor follows the client's wishes then he will violate the existing professional standards and code of conduct but if the auditor does not follow the client then the client can stop the assignment (Saputra et al., 2015).

$\mathrm{H} 1$ : Client pressure has a positive effect on audit quality.

\section{Audit Tenure and Audits Quality}

The period of audit engagement related to quality audit results is still debated as findings that can show the effect on the quality of the audit. The short engagement period is likely due to client dissatisfaction with the quality of the auditor's performance so that the engagement period is terminated before the maximum limit set by the government. The choice made by the company to immediately end the alliance period when the expected quality is not obtained, indicates the tenure audit has little effect on the quality of the audit. On the contrary, the old alliance period has a tendency that the opinions given tend to be the same from year to year. The results of 
the study (Kurniasih \& Rohman, 2014) found that tenure audit variables have a negative and significant effect on audit quality. The relationship between auditors and clients should be able to accommodate optimal audit quality, but too short an alliance period can lead to little specific knowledge of the client so that the audit quality is low. If it is too long it can lead to a decrease in independence and objectivity due to excessive familiarity between the two parties (Permana, 2012).

H2 : Audit tenure has a significant negative effect on the quality of audits.

\section{Client Pressure, Audit Quality and Moderating Effect of Independence}

The independence of a public accountant in the examination of a company or its clients should not be influenced by any party, so that users of financial statements will feel the professional services generated by the auditor. This independence will also affect the full trust of the community as a guarantee of the fairness and appropriateness of financial statements presented with the prevailing principles. The pressure from the client arises when the auditor and the client disagree with some aspects of the results of the financial report testing. Triana (2010) stated that the greater the client pressure, the greater the effect on the auditor's independence. The tendency to show good company performance to stakeholders, becomes the trigger for pressures on auditors. This situation makes auditors experience an ethical dilemma to follow or not the interests of the client (Saputra et al., 2015).

H3 : Client pressure has a significant positive effect on audit quality with independence as variable moderating

\section{Audit Tenure, Audit Quality and Moderating Effect of Independence}

Independence is the expected attitude of a public accountant to be able to disclose client cheats, mental attitudes in giving advice without being influenced, auditors should not have a relationship of interest with the client, and auditors should be mutated to provide services outside of audit (Isaac, 2018). Independence is the most dominant variable affecting Quality (Bawono \& Singgih, 2009). The second common standard of SPAP 2011 (IAI, 2013: SA Section, 150), states that in all cases relating to alliances, independence in mental attitudes must be maintained by an auditor. This standard requires auditors to be independent, meaning it is not easily influenced, as it carries out work in the public interest. Audit tenure is a period of agreement between the auditors of a KAP and the same auditee (Saputra et al., 2015) who should be able to assist the auditor's assessment in testing the client's financial statements. When it comes to auditor independence, it should be that the long relationship between KAP and the client has the potential to cause closeness and improve understanding of each other's conditions and impact the better understanding of the client's business processes, and the risks associated with being aware of the auditor's familiarity with the client. The higher the quality of the auditor, the alliance will be extended.

$\mathrm{H} 4$ : Tenure audit has a significant positive effect on audit quality with independence as variable moderating.

\section{RESEARCH METHODOLOGY}

This research includes quantitative research and was conducted at the Public Accounting Firm (KAP) in Makassar region. The population in this study is all independent auditors working at the Public Accounting Firm registered with IAI Makassar in 2017 and numbering 45 auditors. Sampling using census sampling techniques because it looks at the relatively small population (Sugiyono, 2011). Research data obtained from field research is direct observation on objects that will be researched through data collection techniques in the form of questionnaires and observations and from literature studies by studying literature and other sources related and relevant to the problems and topics being studied (Sugiyono, 2011). In this study, the level of respondents used started from senior auditors, supervisors, managers, senior managers and partners who had worked at public accounting firms (KAP). The reason for selecting these respondents is because of the factors of the length of work and the level that has been considered appropriate with the topics discussed in this study namely client pressure and tenure audits and seeing the impact on the quality of audits reinforced by independence. 
The statistical method used to test the hypothesis is to use a moderated regression analysis (MRA). After all the data in this study is collected, then the data analysis consists of descriptive statistical test, quality test (validity and reability test). Further stiffened classic assumption test to see data normality, multicholinerity test, heteroskedastity test (Ghozali, 2006). To test the research hypothesis, multiple regression models were used with the Moderated Regression Analysis (MRA) approach to determine the influence of independent variables on dependent variables. An MRA model with a moderation variable that is with a model of the absolute value of an independent variable by using SPSS.

The models used in this study are as follows:

$Y=a+\beta 1 X 1+\beta 2 X 2+\beta 3 X 1 X 3+\beta 4 X 2 X 3+\varepsilon$

Description:

Y : Audit Quality

a : Constants

$\beta 1, \beta 2, \beta 3, \beta 4$ : Regression Coefficient

$\mathrm{X} 1$ : Client Pressure

X2 : Audit Tenure

X3 : Auditor Independence

X1X3 : Client Pressure Interaction with Auditor Independence

X2X3 : Audit Tenure Interaction with Auditor Independence

$\varepsilon:$ Error

The regression model is used to see the level of significance provided that if $\mathrm{p}$ value $<(\mathrm{a})+0.05$ and fhitung $>$ ftabel, it means the model is significant and could be used to test the hypothesis. The trust level for hypotheses testing is $95 \%$ or (a) $=0.05$. The basis of decision making is:

1) If Fhitung > Ftabel, then Ha is accepted and HO is rejected

2) If Fhitung < Ftabel, then $\mathrm{Ha}$ is rejected and $\mathrm{HO}$ is accepted

The contribution of a free variable to a bound variable is seen from its Adjusted $R$ Square. Furthermore, the t test was conducted to partially test the hypothesis or effect of free variables on bound variables (Suliyanto, 2011:55). This test was conducted by observing the regression results processed using the SPSS program, i.e. by comparing the significance level of each free variable with $a=0.05$. If the significance level is $t \leq$ 0.05 then the hypothesis presented in this study is diterim (Suliyanto, 2011:67). All of the study's variables were measured on a five-point likert scale from strongly disagreeing (1), strongly disagreeing (2), disagreeing (3), agreeing (4), strongly agreeing (5).

\section{FINDINGS AND DISCUSSION}

Of the 7 public accounting firms in Makassar, who are willing to participate in the research only 4 Public Accounting Firms. The data for this study was obtained using questionnaires that were shared directly with respondents at each public accounting firm.

Validity test results indicate that all instruments used are declared Valid. This is judging by the $r$-count value greater than the r-table. Cronbach's alpha value of all variables used in this study is greater than 0.6. Thus it is concluded that the instrument items for each variable are reliable. The tolerance number of 3 independent variables (Client Pressure, Audit Tenure, and Auditor Independence) has a tolerance value of more than 0.10 and the calculation result of the Variance Inflation Factor (VIF) value calculation also shows the same result, none of the independent variables have a VIF value of more than 10 so it can be concluded that this regression model does not occur multicollinearity. The data normality test results show that the dots spread around the diagonal line, as well as the direction of the spread following the direction of the diagonal line while on the histogram chart gives the distribution pattern does not lean to the left and to the right so that it can be said that the data is distributed normally. The results of the heterokedastisites test showed that the data spread did not form a clear pattern, the data points spread above and below the number 0 on the $\mathrm{Y}$ axis.

The test results obtained show value constant (a) obtained at -0.583 means that if the client pressure variable, Audit Tenure is worth 0 then the amount of audit quality 
that occurs is -0.583 . The regression coefficient $\mathrm{X} 1=1,804$ means that if the client pressure rises by 1 unit, then the audit quality is 1,804 . The regression coefficient X2 = -0.635 means that if the tenure audit rises by 1 unit, then the audit quality is reduced by -0.635 .

The value of Adj R-squared $=58.6$ or $63.6 \%$ can only be explained by the independence of auditors. The remaining $41.4 \%$ is explained by other reasons outside the model. indicates the value of Adj R-squared $=.142$ or of $1.42 \%$ can be explained by the auditor's independence variable. The remaining $98.58 \%$ is explained by other reasons outside the model.

The results of the first hypothesis test (X1) showed a value of significance that was below 0.05. These results suggest a significant influence of client pressure variables on audit quality. The calculated $t$ value of 6,780 is greater than $t$ table 2051 with a significance of 0.000. So the first hypothesis submitted (H1) IS ACCEPTED.

The results of the second hypothesis test (H2) showed a value of significance below 0.05 indicating a significant influence of audit tenure variables on audit quality. The calculated $t$ value of $-3,061$ is smaller than $t$ table which is 2,051 with a significance of 0.005. These results state the second hypothesis (H2) IS ACCEPTED.

The results of the third hypothesis test (H3) show individually the client pressure has a significant positive effect on the quality of the audit. These results state that auditor Independence can be a moderating variable between client pressure and audit quality. Thus the third hypothesis (H3) proposed is ACCEPTED.

The results of the fourth hypothesis test (H4)show that partially audits tenure have a positive effect on audit quality. These results state that auditor independence is incapable of strengthening client pressure relationships and audit quality. Thus the fourth hypothesis (H4) proposed is REJECTED.

\section{Discussion}

Variable client pressure has a positive effect on the quality of the audit means that the increased pressure of the client then the quality of the audit will also increase. The result data analysis, KAP auditors in Makassar are objective and follow the code of conduct of accountants in conducting audits. These results have implications that auditors are likely to be able to cope with pressure from their clients through providing insight and understanding of their clients in detail regarding the code of conduct, professional standards, and legal sanctions that will overshadow the auditor if the auditor does not work in accordance with the applicable rules so that the client will certainly understand the situation faced by the auditor. Maintaining integrity, objectivity and acting honestly, decisively, acting fairly, without being influenced by pressureor requests of certain parties to fulfill their personal interests is the best effort to maintain the quality of audits provided, since the services provided by auditors are used as a basis for decision-making based on financialstatements. This research is in accordance with the agency's theory that is the contractual relationship between principal and agent, the principal delegates responsibility for a particular task in accordance with the agreed contract or decision-making to the agent. An auditor who has pressure from his clients is then encouraged to increase the resulting audit. This research is in line with research (Saputra et al., 2015) which found a significant relationship between client pressure and audit quality.

Variable audit tenure has a negative and significant effect on the quality of audits. The result data analysis, these results show there is a relationship between the client and the auditor. These results provide an idea that auditors who have a relationship with the client will have an impact on the declining quality of the audit due to high emotional feelings so tend to ignore the quality of the audits it produces. The long alliance period makes public accountants feel trust with clients so that there is no strategy development in the audit procedures used and lowers the quality of audits. The emotional connection that occurs is able to change the attitude and behavior of the auditor. Similarly, if there is no relationship between the auditor and the client then the auditor will not hesitate to request data and publish the audit opinion according to the actual circumstances. This research supports research (Sulfati, 2014) which found that the less audit tenure an auditor has, the better the quality of audits produced.

Variable client pressure reinforced by auditor independence proved to have an effect on audit quality. This is in line with the research hypothesis. Client pressure is 
important for an auditor, because with high client pressure, as long as the auditor continues to work with the auditor's independence that binds him, he can still produce equally good audit quality, even better. This is because if the auditor gets a high level of client pressure, the auditor's independence is at stake. So the mindset of auditors awakened and instilled in them that what I did risked my independence as an auditor so that in the implementation of the audit an auditor will get better and produce a quality audit. This research is in accordance with the agency's theory that is the contractual relationship between principal and agent, the principal delegates responsibility for a particular task in accordance with the agreed contract or decisionmaking to the agent. This research is in line with research conducted by (Triana, 2010) which explains that the more client pressure an auditor receives, the greater the effect on the auditor's independence. Thus pressures from clients such as personal, emotional or financial pressures can result in auditor independence and may affect the quality of audits.

Variable audit tenure strengthened by auditor independence proved to have no effect on audit quality. These results are not in line with the research hypothesis. These results provide an idea that the intertwined relationship between the auditor and the client too closely can decrease the auditor's independence attitude and reduce the professionalism of the work of the auditor, resulting in low audit results. This will obviously lead to independence by auditors. In addition, the awarding of facilities or gifts from clients to auditors during the audit process will also affect the independence owned by the auditor. With these grants, it does not close the possibility that little by little, the decisions taken by the auditor in relation to his audit duties will be controlled by the client. In addition, it is very difficult for an auditor to remain independence, especially if in addition to providing audit services for client financial statements, the auditor also provides other non-audit services. Thus, the provision of non-audit services to audit clients, good relationships with clients, or the length of cooperation with clients will make it more difficult for auditors to maintain their independence stance and that will have an impact on the quality of audits produced by auditors. In order to address these three things, the auditor needs to maintain the ethics of the profession in carrying out his work, which in this case is called audit ethics. This research is in accordance with the agency's theory that the agency will take the best course of action in the interests of the principal. The principal will reward the agent's work. The authority and responsibility of the agent and principal are governed by the contract of employment upon mutual consent (Ujiyhanto, 2010). This research is in line with research conducted by Cahyadi (2013) which stated that the assignment of audits for a long time will decrease the independence of auditors because it will make auditors with their clients become not as co-workers but already lead to working partners where partners always support each other.

\section{CONCLUSION AND SUGGESTIONS}

The study found a significant positive effect of client pressure variables (X1) on audit quality. Audit tenure (X2) negatively and significantly affects the quality of audits. The results of the moderating test between client pressure and audit quality indicate that auditor independence can be a variable moderating client pressure and audit quality. Moderating test results show that auditor independence cannot be a moderating variable for audit tenure and audit quality. The sample in this study is few and limited to auditors working in public accounting firms in Makassar. It is suggested that further research can increase and expand the area and number of samples. This research only uses questionnaire methods without interviews, whereas the research will be more relevant between jududl research and the actual state of the auditor profession if accompanied by interviews from several auditors who become respondents, because there can be more complete research. 


\section{REFERENCES}

Abdillah, T. B., \& Sabeni, A. (2013). Faktor-Faktor Yang Mempengaruhi Pergantian Kap, $02,1-12$.

Abedalqader Al-Thuneibat, A., Tawfiq Ibrahim Al Issa, R., \& Ata Baker, R. A. (2011). Do audit tenure and firm size contribute to audit quality? Empirical evidence from Jordan. Managerial Auditing Journal, 26(4), 317-334.

Bawono, R. I., \& Singgih, E. M. (2009). Faktor-Faktor dalam Diri Auditor dan Kualitas Audit: Studi Pada Kap 'Big Four' di Indonesia. Research Gate, (January 2010).

Beneish, D., Baber, B., DeFond, M., Dhaliwal, D., Fons, J., Ghosh, A., ... Miller, D. P. (2004). Does Auditor Quality and Tenure Matter to Investors? Evidence from the Bond Market 756. Journal of Accounting Research (Vol. 42). Retrieved from http://citeseerx.ist.psu.edu/viewdoc/download?doi=10.1.1.468.3397\&rep=rep1\&t ype $=$ pdf.

Cahyadi, Hadi. (2013). Faktor-Faktor yang Mempengaruhi Independensi Akuntan Publik: Studi pada Mahasiswa Jurusan Akuntansi Universitas di Jakarta. Jurnal Akuntansi dan Auditing Indonesia, Vol. 1 No. 2, 36-36.

Coram, P., Glavovic, A., Ng, J., \& Woodliff, D. (2004). The Moral Intensity of Reduced Audit Quality Acts. The University of Department of Accounting and Business, 236.

Dao, M. \& Pham, T. (2014). Audit tenure, auditor specialization and audit report lag. Managerial Auditing Journal, 29(6), 490-512. https://doi.org/10.1108/MAJ-072013-0906.

DeAngelo, L. E. (1981). Auditor Size and Audit Quality. Journal of Accounting and Economics, 3 (3), 183-199.

Ahmad Elqorni 2009. "All Management Insight.Catatan perkuliahan".http:// elqorni.wordpress.com/2009/02/26/

Ghosh, A. \& Moon, D. (2003). Auditor Tenure and Perceptions of Audit Quality. The Accounting Review, 80(2), https://doi.org/10.2139/ssrn.385880.

Ghozali, I. (2006). Aplikasi analisis multivariate dengan program SPSS. Badan Penerbit Universitas Diponegoro.

Hajering, M. S. (2019). Moderating Ethics Auditors Influence of Competence, Accountability on Audit Quality. Jurnal Akuntansi, 23(3), 468-481.

Hendriksen, E.S., dan M. Breda. 1992. Accounting Theory. $5^{\text {th }}$ Edition. USA: Richard DIrwin Inc.

Ikatan Akuntan Publik Indonesia. (2013). Standar Audit ("SA") 150. Jakarta: Salemba Empat.

Ishak, P. (2018). Pengaruh Independensi Auditor, Emotional Intelligence, Spiritual Intelligence Terhadap Perilaku Etis Auditor dan Kinerja Auditor. ATESTASI: Jurnal Ilmiah Akuntansi, 1(1), 85-98.

Kurniasih, M., \& Rohman, A. (2014). Pengaruh Fee Audit, Audit tenure Dan Rotasi Audit Terhadap Kualitas Audit. Diponegoro Journal of Accounting, 3(3), 1-9. Retrieved from http://ejournal-s1.undip.ac.id/index.php/accounting

Lee, T. (1993). Corporate Audit Theory. Chapman \& Hall.

Muslim, M., Pelu, M. F. A., \& Mentari, K. S. (2018). Pengaruh Kompetensi Auditor, Tekanan Ketaatan, dan Kompleksitas Tugas Terhadap Audit Judgment. Bongaya Journal for Research in Accounting (BJRA), 1(2), 08-17.

Nazatul, S., Syed, F., Nazri, M., Hudaib, M., Thahir, A., Nasser, A., \& Wahid, E. A. (2006). Auditor-client relationship: The case of audit tenure and auditor switching in Malaysia. Article in Managerial Auditing Journal. https://doi.org/10.1108/02686900610680512

Panjaitan, C. M. (2014). Pengaruh Tenure, Ukuran Kap Dan Spesialisasi Auditor Terhadap Kualitas Audit. Diponegoro Journal of Accounting, 3(3), 1-12.

Permana, K. X. (2012). PENGARUH MASA PERIKATAN AUDIT DAN UKURAN KAP TERHADAP KUALITAS AUDIT ( Studi Empiris Pada Perusahaan Go Public Yang Terdaftar Di ( Studi Empiris Pada Perusahaan Go Public Yang Terdaftar Di. Universitas Diponegoro. 
Rahim, S. (2016). Pengaruh Kondisi Keuangan Perusahaan, Kualitas Audit Dan Opinion Shopping Terhadap Penerimaan Opini Going Concern. Jurnal Ilmiah Akuntansi Dan Bisnis, 11(2), 75-83.

Rahim, S., Muslim, M., \& Amin, A. (2019). Red Flag And Auditor Experience Toward Criminal Detection Trough Profesional Skepticism. Jurnal Akuntansi, 23(1), 4762.

Rudyawan dan Badera. (2009). Opini Audit Going Concern:Kajian Berdasarkan Model Prediksi Kebangkrutan, Pertumbuhan Perusahaan, Leverage, dan Reputasi Auditor. Jurnal Akuntansi dan Bisnis, 4 (2).

Pratiwi, A., Muslim, M., Rahim, S., \& Pelu, M. F. A. (2020). Kualitas Audit: Ditinjau dari Fee Audit, Risiko Audit dan Skeptisme Profesional Auditor sebagai Variabel Moderating. Ekuitas: Jurnal Pendidikan Ekonomi, 8(1), 9-19.

Saputra, P. I. P., Sujana, E., \& Werastuti, D. N. S. (2015). Pengaruh Gaya Kepemimpinan, Pengalaman Kerja Dan Tekanan Klien Terhadap Kualitas Audit (Studi Pada Empiris Kantor Akuntan Publik Di Provinsi Bali). E-Journal S1 Ak Universitas Pendidikan Ganesha, 3(1).

Sari, K. (2012). Analisis Pengaruh Audit Tenure, Reputasi Kap, Disclosure, Ukuran Perusahaan Dan Likuiditas Terhadap Penerimaan Opini Audit Going Concern. Universitas Diponegoro.

Sugiyono, 2011. Metode Penelitian Kuantitatif, Kualitatif dan Riset Pengembangan. Bandung: Alfabeta. CV.

Sulfati, A. (2014). Pengaruh Fee Dan Tenure Audit Terhadap Kualitas Audit Pada Kantor Akuntan Publik. In Pengaruh Fee Dan Tenure Audit Terhadap Kualitas Audit Pada Kantor Akuntan Publik (pp. 602-610).

Suliyanto. (2011). Ekonometrika Terapan: Teori dan Aplikasi dengan SPSS. Yogyakarta: Penerbit Andi Offset.

Syamsuriana, N., Nasaruddin, F., Suun, M., \& Ahmad, H. (2019). Dampak Perilaku Altruisme, Moral Reasoning dan Kecerdasan Emosional Terhadap Kualitas Audit. ATESTASI: Jurnal Ilmiah Akuntansi, 2(2), 98-110.

Triana, H. (2010). Pengaruh Tekanan Klien Dan Tekanan Peran Terhadap Independensi Auditor Dengan Kecerdasan Spiritual Sebagai Variabel Moderating. Universitas Islam Negeri Syarif Hidayatullah Jakarta.

Ujiyantho, Arief. (2010). Asimetri Informasi dan Manajemen Laba: Suatu Tinjauan dalam Hubungan Keagenan. Institut Akuntan Publik Indonesia.

Wahyuni, W. (2019). Deteksi Kecurangan Laporan Keuangan Oleh Kantor Akuntan Publik. ATESTASI: Jurnal Ilmiah Akuntansi, 2(1), 41-50. 